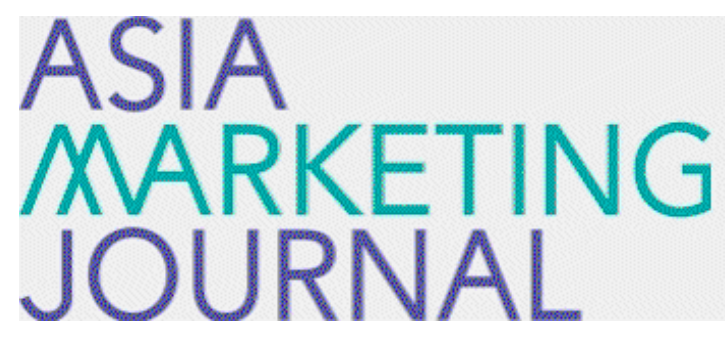

ASIA MARKETING JOURNAL

Volume 11 | Issue 3

Article 6

10-30-2009

\title{
A Study on the MOT of Household Telecommunication Services
}

Minhee Son

Kyesook Han

Hyoyeol Lim

Follow this and additional works at: https://amj.kma.re.kr/journal

Part of the Marketing Commons

\section{Recommended Citation}

Son, Minhee; Han, Kyesook; and Lim, Hyoyeol (2009) "A Study on the MOT of Household Telecommunication Services," Asia Marketing Journal: Vol. 11 : Iss. 3 , Article 6.

Available at: https://doi.org/10.53728/2765-6500.1396

This Article is brought to you for free and open access by Asia Marketing Journal. It has been accepted for inclusion in Asia Marketing Journal by an authorized editor of Asia Marketing Journal. 


\title{
A Study on the MOT of Household Telecommunication Services: The Effects of MOT Experience and Service Quality on Product Evaluations across Different Phases of the Product Life Cycle
}

\author{
Son, Minhee* \\ Han, Kyesook** \\ Lim, Hyoyeol***
}

\begin{abstract}
With the intensity of competition and the standardization of technical attributes in telecommunications service market increasing, differentiated activity and customer experience in service encounter is regarded as an important means for creating customer value, however, there is a dearth of good literature examining what MOT activity is composed of according to consumption chain, and how service quality of MOT has influenced customer performance. Especially there exist various services across different phase of Product life cycle(PLC) in household telecommunication service market, customer requirement for MOT might depend on whether its phase is introduction-growth stage or maturity-decline stage, the empirical study is completely lacking.

This study classified household telecommunication services into two types by PLC, VOIP and IPTV as Introduction-growth stage services, Internet and PSTN as maturity-decline stage service, and investigated whether there exists a gap between service types in how consumer have experienced MOT, what they consider as important and the relative importance of quality dimension how service quality of MOT has influence on consumer performance. The empirical result from 858 participants shows that there is a difference in consumer experience and requirements across different phases of the PLC, tangibles and assurance are regarded as the most important service quality factors which have a positive influence on customer performance (consumer satisfaction, repurchase intention and word of mouth) at the introduction-growth stage, whereas, reliability, empathy and interactivity are at the maturity-decline stage. Finally, managerial implication is made, limitation is clarified and a direction for further studies is suggested.
\end{abstract}

Key words: Household telecommunication services, MOT, Service quality, Product life cycle

* Research Director, Ph.D., KT Home Customer Strategy BU.

** Full-time Lecturer, Department of Distribution Management, Yuhan University.

**** Senior Researcher, KT Home Customer Strategy BU. 


\section{Introduction}

Nowadays, with the boundaries between telecommunications, broadcasting and entertainment continuing to blur, telecommunication industrial landscape is characterized by a collective competition, a diversity of customer requirements, and the continued emergence of new services. In South Korea, telecommunications services market has experience a tremendous growth over the last few decades. KT, SK Telecom, LG Group, telecommunications operators, are already struggling to keep growth alive in a saturating domestic market and the industry at the moment seems to lack new, compelling technologies and services to generate real excitement. Especially, household telecommunications services such as fixed line telephone(PSTN), broadband internet have been mature, telecommunications carriers are introducing new services - Internet Protocol TV (IPTV), Voice of Internet Protocol (VoIP) - to find a new opportunity.

Service providers are now operating in a highly competitive environment with tight margins and fleeting customer loyalty. Revenue leakage, customer churn and ineffective customer service have put pressure on the profitability of the service providers. In the wake of these changing dynamics, the telecommunication operators face a number of significant challenges. Retaining existing customer in high churn market has become more difficult and costly. Similarly, customer acquisition for new telecommunications services is becoming more elusive than ever as potential customer want to receive more differentiated services to choose from and service operators offer attractive deals to lure prospects.

In light of these challenges, telecommunications operators may require signigicant investment of time and effort. Differentiated activity and customer experience in service encounter is regarded as an important means for creating customer value, however, there is a dearth of good literature examining what MOT activity is composed of according to consumption chain, and how service quality of MOT has influenced customer performance. Especially there exist various services across different phase of Product life cycle (PLC) in household telecommunication service market, customer requirement for MOT might depend on whether its phase is introductiongrowth stage or maturity-decline stage, The empirical study is completely lacking.

This study classified household telecommunication services into two types by PLC, VoIP and IPTV as Introduction-growth stage services, Internet and PSTN as maturity-decline stage service, and investigated whether there exists a gap between service types in how consumer have experienced MOT, what they consider as important and the relative importance of quality dimension how service quality of MOT has influence on consumer performance. 


\section{Research Questions and Methods}

Considering that prior studies on service encounter throughout the whole consumption chain (CC) in telecommunications industry are limited, we first take exploratory research by conduc- ting mini group discussion (MGD) of 4 groups each consisting of $4 \sim 6$ people. The results are shown in the $\langle$ Table 1$\rangle$.

Next, this study developed the following two stage research model which reflects the relationships as stipulated in research objective stated earlier. The growing importance of service

〈Table 1〉 Service Encounter in Telecommunications Industry

\begin{tabular}{|c|c|c|c|}
\hline $\mathrm{CC}$ & service encounter & $\mathrm{CC}$ & service encounter \\
\hline \multirow{8}{*}{$\begin{array}{c}\text { Brand } \\
\text { searching } \\
\text { /Awareness }\end{array}$} & $\begin{array}{l}\text { 1) inquiry for product information through visiting } \\
\text { store }\end{array}$ & \multirow{6}{*}{$\begin{array}{c}\text { Usage } \\
\text { (continued) }\end{array}$} & 22) claim troubleshooting through visiting counter \\
\hline & 2) visiting customer experience space & & 23) add or change services through phone call \\
\hline & 3) recommendation from acquaintance & & 24) add or change services through web site \\
\hline & $\begin{array}{l}\text { 4) searching for product information through the } \\
\text { web site }\end{array}$ & & $\begin{array}{l}\text { 25) add or change services through visiting } \\
\text { counter }\end{array}$ \\
\hline & $\begin{array}{l}\text { 5) inquiry for product information through phone } \\
\text { calls }\end{array}$ & & $\begin{array}{l}\text { 26) receiving usage guideline through call/text } \\
\text { message }\end{array}$ \\
\hline & 6) product information leaflet & & 27) receiving billing request form \\
\hline & 7) calls for sign-up information & \multirow{10}{*}{$\begin{array}{l}\text { Retainment } \\
\text { /Repair }\end{array}$} & 28) $\mathrm{A} / \mathrm{S}$ request \\
\hline & 8) sales promotion & & 29) A/S service scheduling \\
\hline \multirow{8}{*}{$\begin{array}{l}\text { Subscription } \\
\text { /Delivery }\end{array}$} & 9) apply for subscription through visiting counter & & 30) looking up / completion of repairs \\
\hline & 10) apply for subscription through phone call & & 31) confirmation call for $\mathrm{A} / \mathrm{S}$ service \\
\hline & 11) apply for subscription through the web site & & 32) regularly feedback check up \\
\hline & 12) confirm notification & & 33) customer cooperation \\
\hline & 13) receipt of gifts for subscribers & & 34) congratulation call on special days \\
\hline & 14) appointment of visiting for installation & & 35) events performance for only users \\
\hline & 15) completion of installation & & 36) membership performance for only users \\
\hline & 16) notification call after installation & & 37) benefits for long-term users / VIP customers \\
\hline \multirow{5}{*}{ Usage } & 17) inquiry on users guide through phone calls & \multirow{5}{*}{ Disposition } & 38) apply for cancellation \\
\hline & 18) inquiry on users guide through the web site & & 39) guidance for withdrawal \\
\hline & 19) inquiry on users guide through visiting counter & & 40) receive benefit for withdrawal \\
\hline & 20) claim troubleshooting through phone calls & & \multirow{2}{*}{ 41) fill cancellation } \\
\hline & 21) claim troubleshooting through the web site & & \\
\hline
\end{tabular}


encounter and service quality of MOT in the telecommunications industry leads us to examine the following questions concerning the relationships among service encounter, service quality and customer performance.

Research Question 1: The impact of customer encounter experience will differ according to phases of the product life cycle of household telecommunication services.

Research Question 2: The dimensions of service quality will influence differently on customer performance according to phases of the product life cycle of household telecommunication services.

Data was collected using self-administerd questionaries from each service users through $\mathrm{e}^{-}$ mail survey. A convenience sampling was used to select the respondents for the study. A total of 858 questionnaires was collected, used for data analysis. SPSSWIN(Ver.10) was used for data analysis.

\section{Research Findings}

For research questions testing, scatter plot and multi-regression analysis was conducted by using SPSS 10.0 statistics package. For regression analysis, we calculated the mean value of each construct. Results are as follows. First, there is a difference in consumer experience and requirements across different phases of the PLC. Next, tangibles and assurance are regarded as the most important service quality factors which have a positive influence on customer performance (consumer satisfaction, intention to repurchase and intention to recommend) at the introduction-growth stage, whereas, reliability, empathy and interactivity are at the maturity-decline stage.

〈Figure 1〉 Research Framework

Research Question 1

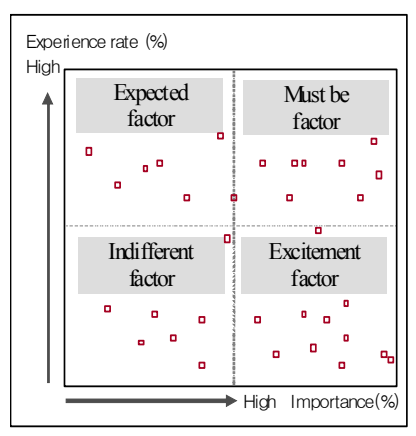

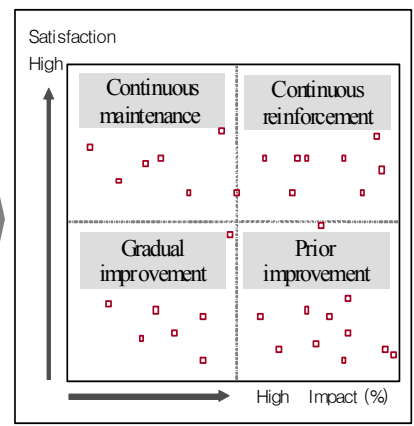

Research Question 2

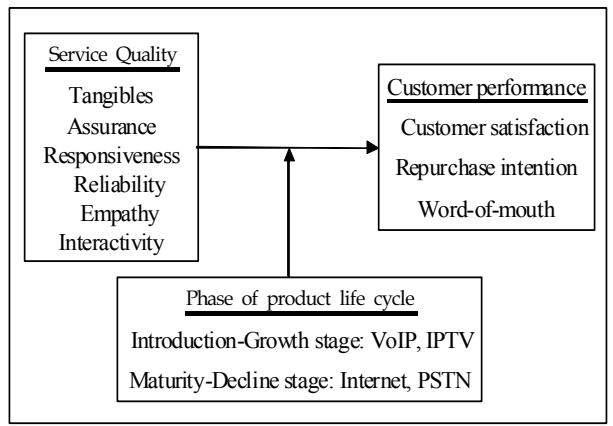


〈Table 2〉 Regression of the Service Quality on Customer Performance: Introduction-Growth Stage services

\begin{tabular}{|c|c|c|c|c|c|c|}
\hline \multirow{2}{*}{$\begin{array}{c}\text { Independent } \\
\text { Variables }\end{array}$} & \multicolumn{5}{|c|}{ Dependent Variables : Standardized coefficients(t-value) } \\
\cline { 2 - 7 } & $\begin{array}{c}\text { Customer } \\
\text { satisfaction }\end{array}$ & $\begin{array}{c}\text { Re-purchase } \\
\text { intention }\end{array}$ & $\begin{array}{c}\text { Word of } \\
\text { mouth }\end{array}$ & $\begin{array}{c}\text { Customer } \\
\text { satisfaction }\end{array}$ & $\begin{array}{c}\text { Re-purchase } \\
\text { intention }\end{array}$ & $\begin{array}{c}\text { Word of } \\
\text { mouth }\end{array}$ \\
\cline { 2 - 7 } & $.40(2.29)^{* *}$ & $.08(0.51)$ & $.58(2.91)^{* * *}$ & $.09(0.94)$ & $.10(0.94)$ & $.21(2.18)^{* *}$ \\
Tangibles & $.17(0.63)$ & $.19(1.05)$ & $.37(1.21)$ & $.02(0.20)$ & $.11(0.86)$ & $.16(1.41)$ \\
Reliability & $.05(0.27)$ & $.08(0.41)$ & $.30(1.27)$ & $.23(1.90)^{*}$ & $.22(1.70)^{*}$ & $.04(0.35)$ \\
Responsiveness & $.42(2.94)^{* * *}$ & $.08(0.62)$ & $-.20(-1.24)$ & $.24(2.45)^{* *}$ & $.14(1.33)$ & $.28(2.87)^{* * *}$ \\
Assurance & $.20(1.11)$ & $.33(2.10)^{*}$ & $-.05(-0.26)$ & $-.10(-0.87)$ & $-.17(-1.40)$ & $.07(0.67)$ \\
Empathy & $-.13(-0.81)$ & $.02(0.16)$ & $-.20(-1.08)$ & $.42(3.79)^{* * *}$ & $.44(3.71)^{* * *}$ & $.15(1.34)$ \\
Interactivity & .818 & .849 & .757 & .618 & .557 & .614 \\
\hline $\mathrm{R}^{2}$ & $11.984(0.0)$ & $14.975(0.0)$ & $8.312(0.0)$ & $28.341(0.0)$ & $22.030(0.0)$ & $27.841(0.0)$ \\
\hline F-vale(P-value)
\end{tabular}

${ }^{*} \mathrm{P}<.10,{ }^{* *} \mathrm{P}<.05,{ }^{* * *} \mathrm{P}<.01$

〈Table 3〉 Regression of the Service Quality on Customer Performance: Maturity-Decline Stage services

\begin{tabular}{|c|c|c|c|c|c|c|}
\hline \multirow{3}{*}{$\begin{array}{c}\text { Independent } \\
\text { Variables }\end{array}$} & \multicolumn{6}{|c|}{ Dependent Variables : Standardized coefficients(t-value) } \\
\hline & \multicolumn{3}{|c|}{ Broadband Internet } & \multicolumn{3}{|c|}{ PSTN } \\
\hline & $\begin{array}{l}\text { Customer } \\
\text { satisfaction }\end{array}$ & $\begin{array}{c}\text { Re-purchase } \\
\text { intention }\end{array}$ & $\begin{array}{l}\text { Word of } \\
\text { mouth }\end{array}$ & $\begin{array}{l}\text { Customer } \\
\text { satisfaction }\end{array}$ & $\begin{array}{l}\text { Re-purchase } \\
\text { intention }\end{array}$ & $\begin{array}{l}\text { Word of } \\
\text { mouth }\end{array}$ \\
\hline Tangibles & $-.06(-1.16)$ & $.02(0.37)$ & $-.01(-0.11)$ & $.04(0.63)$ & $-.01(-.08)$ & $.01(0.74)$ \\
\hline Reliability & $.25(3.59)^{* * *}$ & $.23(3.34) * * *$ & $.34(4.78)^{* * *}$ & $.23(2.86)^{* * *}$ & $.25(2.77)^{* * *}$ & $.27(2.84)^{* * *}$ \\
\hline Responsiveness & $.17(2.52)^{* *}$ & $.17(2.56)^{* *}$ & $.18(2.65)^{* * *}$ & $.12(1.56)$ & $-.01(-0.01)$ & $.08(0.96)$ \\
\hline Assurance & $.01(.28)$ & $-.05(-0.91)$ & $.06(1.05)$ & $.01(0.11)$ & $-.06(-0.81)$ & $.09(1.27)$ \\
\hline Empathy & $.16(3.06)^{* * *}$ & $.11(2.01)^{* *}$ & $.01(0.24)$ & $.17(2.57)^{* *}$ & $.23(3.09)^{* * * *}$ & $.10(1.34)$ \\
\hline Interactivity & $.29(5.46)^{* * *}$ & $.35(6.69) * * *$ & $.24(4.45)^{* * *}$ & $.35(5.16)^{* * *}$ & $.41(5.40)^{* * * *}$ & $.25(3.15)^{* * * *}$ \\
\hline $\mathrm{R}^{2}$ & .566 & .568 & .554 & 642 & .558 & .528 \\
\hline F-vale(P-value $)$ & $101.860(0.0)$ & $102.540(0.0)$ & $96.989(0.0)$ & $72.178(0.0)$ & $50.699(0.0)$ & $44.868(0.0)$ \\
\hline
\end{tabular}

${ }^{*} \mathrm{P}<10,{ }^{*} \mathrm{P}<.05,{ }^{*} * \mathrm{P}<.01$

\section{Discussions}

The purpose of this study was to identify the underlying service encounter throughout the whole consumption chain and to understand the relationship between the dimensions of service quality and customer performance in telecommunications industry. This study classified household telecommunication services into two types by PLC, VOIP and IPTV as introductiongrowth stage service, Internet and PSTN as 
〈Table 4〉 Summary of Results

\begin{tabular}{|c|c|c|c|c|c|c|c|c|c|c|c|c|}
\hline \multirow{2}{*}{$\begin{array}{c}\text { Independent } \\
\text { Variables }\end{array}$} & \multicolumn{4}{|c||}{ Introduction-Growth Stage services } & \multicolumn{5}{c|}{ Maturity-Decline Stage services } \\
\hline & \multicolumn{4}{|c|}{ VoIP } & \multicolumn{3}{|c|}{ IPTV } & \multicolumn{3}{c|}{ Internet } & \multicolumn{3}{c|}{ PSTN } \\
\hline & CS & RI & WOM & CS & RI & WOM & CS & RI & WOM & CS & RI & WOM \\
\hline Tangibles & $* * *$ & & $* * *$ & & & $*$ & & & & & & \\
\hline Reliability & & & & & & & $* * *$ & $* * *$ & $* * *$ & $* * *$ & $* * *$ & $* * *$ \\
Responsiveness & & & & $*$ & $*$ & & $* *$ & $* *$ & $* * *$ & & & \\
\hline Assurance & $* * *$ & & & $* *$ & & $* * *$ & & & & & & \\
Empathy & & $*$ & & & & & $* * *$ & $* *$ & & $* *$ & $* * *$ & \\
Interactivity & & & & $* * *$ & $* * *$ & & $* * *$ & $* * *$ & $* * *$ & $* * *$ & $* * * *$ & $* * * *$ \\
\hline
\end{tabular}

${ }^{*} \mathrm{P}<10,{ }^{* *} \mathrm{P}<.05,{ }^{* * * *} \mathrm{P}<.01$

maturity-decline stage service, and investigated whether there exists a gap between service types in how consumer have experienced MOT, what they consider as important and the relative importance of quality dimension how service quality of MOT has influence on consumer performance. The finding of this study indicate that service quality dimensions(Tangibles, Reliability, Responsiveness, Assurance, Empathy, Interactivity) have positive and significant effect on customer performance(satisfaction, repurchase intention, word of mouth). The study also found that there are significant differences in customer performance across phase of Product life cycle(PLC) in household telecommunication service market.

These results contributed to the service encounter and service quality literature in some ways. First, the study sought to fulfil some theoretical gaps that emerged from the service related literature and increased our understan- ding of complex relationship between service quality of MOT and performance. Second, the study confirms service quality literature that advocates that there is positive and significant relationship between the dimensions of service quality and customer performance, and reliability, empathy and interactivity have a stronger effect on performance relative to tangibles, assurance and responsiveness at the maturitydecline stage.

Although this research paper has answered its questions, the authors of this paper believe that some areas are worth to be investigated in future research endeavors. For example, future research can extend this research by including other telecommunications services or other service sectors such as insurance, health care. Another potential area of research is to consider the constructs which moderate relationship between service quality dimension and performance. 


\section{Reference}

Korea communications commission, www.kbc.go.kr

KT, www.kt.com

LG dacom, www.lgdacom.net

LG powercomm, www.powercomm.com

SK broadband, www.skbroadband.com

Ambert, A. M.(1994), “A Qualitative Study of Peer Abuse and Its Effects: Theoretical and Empirical Implications," Journal of Marriage and the Family, 56, 119-130.

Bitner, J. (1990), "Evaluating Service Encounters: The Effects of Physical Surrondings and Employee Responses," Journal of Marketing, 54(April), 60-82.

Bitner, J.(1992), "Servicescape: The Impact of Physical Surroundings on Customers and Employees," Journal of Marketing, 56(April), 57-71.

Carrillat, Francois, Fernando Jaramilo, and Prakash Mulki(2009), "Examining the Impact of Service Quality: A Meta-Analysis of Empirical Evidence," Journal of Marketing Theory and Practice, 17(2), 95-110.

Carman, J. M. (1990), "Consumer Perceptions of Seervice Quality: An Assessment of the SERVQUAL Dimension," Journal of $R^{-}$ tailing, 66(1), 33-55.

Challagalla, Goutam, R. Venkatesh, and A. K. Kohli(2009), "Proactive Postsales Service: When and Why Does It Pay Off?," Journal of Marketing, 73(March), 70-87.
Colgate, Mark and Nicholas Alexander(2002), "Benefits and Barriers of Product Augmentation: Retailers and Financial Service," Journal of Marketing Management, 18, 105123.

Cronin, J. Joseph and Steven A. Taylor(1992), "Measuring Service Quality: A Reexamination and Extension," Journal of Marketing, 56(July), 55-68.

Denzin, N. K., and Y. S. Lincoln(1994), "Introduction: Entering the Field of Qualitative Research”. In N.K. Denzin and Y. S. Lincoln(eds.), Handbook of Qualitative Research, Thousand Oaks, CA: Sage Publications, Inc. 1-17.

Eun, Hyunji, Seong-cheol Kim(2006), "Developing End-User Oriented Quality Dimensions for BcN Service," Journal of the Korean OR and MS Society, 23(3), 119-132.

Eshghi, S. Roy, S. Ganguli(2008), "Service Qaulity and Customer Satisfaction: An Empirical Investigation in Indian Mobile Telecommunications Services," Marketing Management Journal, 18(2), 119-144.

Furrer, Oliver, Ben Shaw-Ching Liu, and D. Sudharshan(2000), "The Relationships Between Culture and Service Quality Perceptions: Basis for Cross-Cultural Market Segmentation and Resource Allocation," Journal of Service Research, 2(4), 355-371. Galesic, M.(2005), "Effects of Questionaire Length on Quality of Responses in Web Surveys" Proceedings, ESF(European Science 
Foundation) Workshop on Internet Survey

Methodology, Dubrovnik, September, 26-28.

Gronroos, C. A. (1984), "Service Quality Model

and Its Marketing Implications," European

Journal of Marketing, 18(4), 36-44.

Kim, Dae Up, Jae Sin Oh(2006), “A Structure on Mobile Service Quality," Journal of the Korea Service Management Society, 7(3), 51-82.

Lee, Thae Min, Sun A La, Sang Yeon Song (2009), "MOBISQUAL: Dimensionalizing and Measuring Mobile Internet Service Quality,” Korean Marketing Review, 24 (1), 145-179.

Levitt(1965), "Exploiting the Product Life Cycle,"

Harvard Business Review, 43(6), 81-94.

Levitt(1980), "Marketing Success Through Differentiation of Anything," Harvard Business Review, 85(1), 83-91.

Lim, H., R. Widdows, and Park J.(2006), "M-Loyalty: Winning Strategies for Mobilie Carriers," Journal of Consumer Marketing, 23(4), 208-218.

Lovelock, H. C.(1991), Managing Service $2^{\text {nd }}$ ed.), Prantice-Hall, Englewood Fliffs, NJ.

MacMillan, I. C. and R. G. McGrath(1997), "Discovering New Points of Differentiation," Harvard Business Review, July-August, 133-145.

Mahajan, Vijay, Eitan Muller, and Frank M. Bass(1990), "New Product Diffusion Models in Marketing: A Reveiw and Directions for Research," Journal of Marketing, 54(1),
$1-26$.

Meyer, C. and A. Schwager (2007), "Understanding Customer Experience," Harvard Business Review, Feb., 117-126.

Min, Jae Hyung, Myung-Hui Yoon(2006), "Quality Attributes of Internet Telephony Service and Their Impact on Customer Satisfaction, Customer Loyalty and Customer Performance," Journal of the Korean OR and MS Society, 23(3), 133-156.

Normann, R.(1991), Service Management: Strategy and Leadership in Service Business, 2nd eds., John Wiley\&Sons.

Oh, Myung-Keun(2007), "A Study of the Effectiveness and Interaction of Service Quality Dimensions," Journal of Tourism and Leisure Research, 19(1), 185-203.

Parasuraman, A., Valarie Zeithaml, and Leonard Berry(1988), "SERVQUAL: A MultiItem Scale for Measuring Consumer Perceptions of Service Quality," Journal of Retailing, 64(Spring), 12-40.

Park, Yoon Seo, Seung In Lee, Sam Kwon Kim(2007), "Measuring the Service Quality of Mobile Internet and Studying the Effects on Marketing Performance," Journal of Quality Management, 35(2), 63-83.

Rogers, Everett M.(1983), Diffusion of Innovations. New York: The Free Press.

Schmitt, B.(2003), Customer Experience Management, Wiley \& Sons, Inc.

Shostack, L.(1985), Panning the Service Encounter in Czepiel, A. J., Solomon R. M. 
and Suprenant, F. C. (eds), The Service Encounter, Lexington Books, New York, NY, 243-254.

Song, Gwang Suk, Han Joo Yoo(2001), "Applications Papers: A Study on the Impact of Service Quality on the Customer Satisfaction in the Business - to - Consumer (B2C) E - Commerce," Journal of Quality Management, 29(4), 116-132.

Solomon, R., C. Surprenant, A. Czepiel, and G. Gutman(1985), "A Role Theory Perspective on Dyadic Interaction: The Service Encounter," Journal of Marketing, 49(1), 99-111.

Storey, C. and C. J. Easingwood(1998), "The Augmented Service Offering: A Conceptualization and Study of its Impact on New Service Success", Journal of Product Innovation Management, 15(4), 335-351.

Suprenant, F. and M. Solomon(1987), "Predictability and Personalization in the Service Encounter," Journal of Marketing, 51(April), 86-96.

Tan, F. and C. Chou(2008), "The Relationship Between Mobile Service Quality, Perceived Technology Compatibility, and Users' Per- ceived Playfulness in the Context of Mobile Information and Entertainment Services," 24(7), 649-671.

Wood, Lisa M.(1996), “Added Value: Marketing Basics?", Journal of Marketing Management, 12, 735-755.

Yang, Hyo-seok, Do-Kyoung Sung, ChoonBurn Yoo(2008), "Literature Review of Service Quality: Focused on Korean $\mathrm{Re}^{-}$ search Papers," Journal of Quality Management, 36(3), 112-129.

Yi, You Jae, Jun Youb Lee(2001), “A Reexamination of the Measurement and Consequences of Service Quality: Development and Application of the KS - SQI Model," Korean Marketing Review, 16(1), 1-26.

Yoo, Han Joo, Gwang Suk Song(2004), “A Study on the Service Quality Level and Switching Barriers in the Retail Industry -Comparing Department Store with Discount Store-," Journal of Quality Management, 32(2), 109-131.

Zeithaml, V. A., L. L. Berry, and A. Parasuraman (1988), "A Communication and Control Process in the Delivery of Service Quality," Journal of Marketing, 52, 37-47. 